\title{
Revision to Theory of Constraints
}

\author{
Sofía Estellés Miguel, Teresa Barbera Ribera, José Miguel Albarracín Guillem, \\ and Carlos Manuel Dema Pérez
}
Departamento de Organización de Empresas, Universidad Politécnica de Valencia, Camino de Vera s/n 46022 Valencia
soesmi@omp.upv.es, mabarri@upvnet.upv.es,
jmalbarr@omp.upv.es, cmdema@omp.upv.es

\begin{abstract}
It's intended to give an approximation to the Theory of Constraints (TOC), to achieve that goal we explain the conceptual bases, the thinking process, the flow management and later on we will focus on its application into production, also known as DBR (Drum-Buffer-Rope). A usual critic in the academic environment is that TOC techniques produce results that are feasible but not always optimal. Although defenders of TOC reply that optimal results are very elegant but need to reduce or eliminate variability of systems, while TOC is an appropriate method to work with variable worlds, such as the real one. Anyway, this creates a gap relative to production programming and sequencing, establishment of batch sizes, measures of initial buffer size and determination of the optimal product mix.
\end{abstract}

Keywords: DBR, Drum-Buffer-Rope, Theory of Constraints, TOC, Goal, Thinking-Process.

\section{Introduction}

TOC is a systemic methodology of company management and improvement. The concepts in which is based are compiled from most of the literature published over the topic, we will highlight the concepts goal and constraint. Contribution of TOC can be divided into 2 groups [1]:

- Thinking Process: Set of tools that ease the analysis and search of systemic solutions for problematic situations.

- Robust applications based on Systemic thinking and Operations research methods: Production, Operations, Supply Chain, Project Management, Decisionmaking, etc....

There also exist some studies showing evidence that from the start of introducing TOC, companies achieve to increase its production quantity at the same time as they reduce both inventory and cycle time [2]; [3]; [4]; [5]. Some academicals tests validate that using TOC techniques produce a better performance than using MRP, Lean Manufacturing and JIT [6], [7]; [8]; [9]; [10]; [11]. The result of these studies show that TOC systems produce higher production levels as they reduce inventory, production time or "lead time", and the cycle time standard deviation. 


\section{Theory of Constraints}

It is a systemic business management and improvement methodology. It's based on the following concepts [12]:

1. The goal of any profit company is to earn money in a regular way. If it does not it is because its constraints do not let it.

2. In any company just exist a few constraints.

3. A constraint can be physical or political.

4. Systemic thought defends that the maximum performance of a system is achieved by the maximum performance of its constraints.

\subsection{Continuous Improvement Cycle}

We cannot talk about TOC without mentioning the continuous improvement process in which is based, [13]:

1. IDENTIFY the limitation of the system.

2. Decide how to EXPLOIT the limitation of the system.

3. SUBORDINATE everything else to the previous decision.

4. ELEVATE the limitation of the system.

5. If, in a previous step, the limitation has been broken, return to step 1. Do not let that INERTIA turns out into a limitation of the system.

\section{Evolution of TOC}

When trying to perform a study or a chronology of the TOC philosophy evolution, its evolution can be segmented into 5 eras [14]:

1. The OPT era (Optimized Production Technology). The secret algorithm.

2. "The Goal" era, using DBR programming (Drum-Buffer-Rope).

3. "The barn syndrome" era, using the TOC measuring systems.

4. The "It's not matter of luck" era, applying reasoning processes to various topics.

5. The "Critical Chain" era or TOC applied to Project Management.

We can see the evolution in the figure 1.

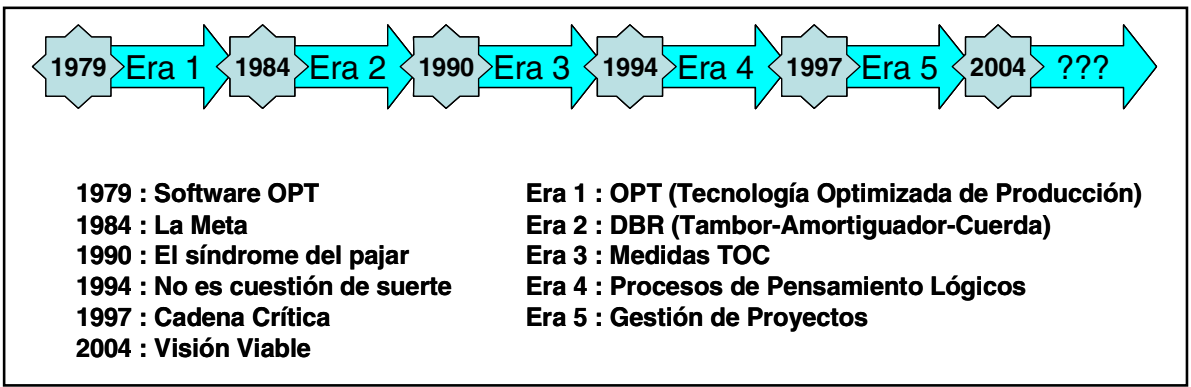

Fig. 1. Eras of TOC evolution. Source: Own adaptation from [14] 
The mechanisms used by TOC for each of its Management processes, instead of following the eras chronologically, although they could be easily addressed to the eras mentioned before.

The application of TOC techniques has been discussed in literature in a variety of Management sub-disciplines:

- In production: [15]; [4]; [16]; [17], [5].

- Project management: [18], [19]; [20]; [21]; [22]; [23]; [24].

- Distribution: [25]; [26].

- Supply Chain management: [27]; [28]; [29].

- Improvement processes: [30]; [31]; [32].

\section{Reviews to TOC}

Besides the reviews already mentioned in the introduction, it is usually reproached to TOC that most of the knowledge that is used is based on already existent theories:

- TOC is based on systemic thought [33].

- The Solutions that propose TOC for operations and Project Management are based on the queues theory and the statistical theory of aggregation. [34].

- The Concepts proposed by TOC for Decision making are the method "Direct Costing" that appears in management books from the fifties [1].

- The solution that TOC proposes for Distribution is basically the application of the aggregation theory [34].

- The thinking processes of TOC are simply the verbalization of common sense, and have also been extracted from Edward De Bono's books. [35].

The true achievement of Dr. Goldratt and his team (Donn Novotny, Dale Houle, Dee Jacobs, Oded Cohen, etc) has been to develop a method to be able to use these Tools together in the resolution of problems. The worth has been to find a way for these tools to be used in companies with a high chance of producing excellent results.

\section{Contributions of TOC}

\subsection{Thinking Process}

The reasoning processes are an analytical tool developed by the Abraham Y. Goldratt Institute (AGI) [1], but based on the reasoning processes from the author Edward de Bono [35].

The Tools used in the reasoning processes are based on the systemic use of the logical relationships of cause-effect, necessity and generalization, so once acquired they result easy to handle and to understand.

They are used for [36]:

- To achieve an exact understanding of any aspect of reality and to find way of improving it (understanding of reality). 
- To improve the communications capacity, because intuition is not enough to express common sense and to achieve understanding with the others.

Tools uses are:

- Current reality tree.

- Conflicts elimination.

- Future reality tree.

- Pre-requirements tree.

- Transition tree.

These tools are used to answer the following questions.

- What should be changed?

- What should we change to?

- How to produce the change?

Not every tool has to be used at the same time, depending on the kind of problem are used some tools or others.

The cost/benefit balance results more favourable for the use of reasoning processes as they become more complex and therefore more difficult to maintain in a strictly intuitive level [37].

\subsection{TOC in the Commercial Area}

It is a generic application of the reasoning processes used in TOC. The application of TOC in Marketing and sales has as goal the adequate orientation of the company in dynamic, uncertain, open and highly competitive today markets.

The high level of uncertainty in the markets demands to provide the company with flexibility of offer. TOC looks for increasing that flexibility both in the short and the long term to reduce the vulnerability of the company towards the uncertainties of the demand and the attacks of the competition [36].

The keys of flexibility are the market dynamic segmentation starting from offers that include competitive differentials and in the long term, the concept of strategical limitations, and essential competences over which to spread the offers in function of the alternations in the markets. Segment the market, not the resources [38].

We could talk widely about the differences that exist between the TOC commercial approach and the traditional offers, but this is not the goal of the present article. But it could also be resumed saying that we are looking for solutions "win to win" [39] (process in which both sides win equally).

Examples of this application can be found in various publications: [26], [40]; [38]; [41]; [42].

\subsection{Flow Management in TOC}

The existence of flows is a common characteristic of the production environments (industrial or services), projects and distribution.

The TOC systemic management model is applied to the management of these flows in the environments defined in function of the following premises [36]: 
- The uncertainty existent in any environment and the dependence between the flows processes entail that its output is not determined by all the processes it goes through.

- The final output must be planned in function of the clients and the resource that is pretended to regulate the flow, in other words, the desirable tactical limitation (DTL). If the limitation is inside the system.

- Processes performed by DTL must be planned. This should always be done whenever it is not the demand what determines the volume of output for excess of system capacity. This happens if the limitation is located in the market.

- Buffers (pools of shared resources among non-planned resources), are the mechanism that make possible the subordination of the rest of the system to what was planned letting a higher flexibility.

- Buffers can be time-related (production and projects) and resource-related in ace of distribution.

TOC Flow Management applications are known as:

- DBR (Drum-Buffer-Rope) in Production.

- Projects Critical Chain. Reposition in Distribution.

In this section are going to be explained the areas previously mentioned except DBR, that will be explained in more retail in the next section.

\subsubsection{Application to Project Management}

Its goal is to conclude the projects within time, budget and scope. In Project Management 2 limitations interact: time and resources. TOC handles them subordinating project to the "critical chain" through a concentrated buffers in selective points strategy. [18]; [24].

According to Goldratt two problems can be found when working in projects, the student's syndrome and the Parkinson's Law (the work expands to fill all available time), therefore a Project has great chances of not being finished on time. [38].

The buffer concept and its application on activities planning are considered an innovation respect the traditional schema of time Management and a big contribution to Project Management [43].

To evaluate the state of a project it is used: [38]:

1. Critical chain accomplishment percentage.

2. Rate between product buffer consume and the already finished critical chain.

3. Penetration rate in the Project buffer.

The difference in the TOC Project Management is based on one side by the treatment of resources for which different activities of the Project compete, and on the other hand TOC takes into account the almost general fact that the intensity of the effort dedicated to one activity is concentrated on the time immediately previous to the milestone of the ending of itself. Protect the critical chain and not each one of the activities [18]; [24].

\subsubsection{Application to Distribution}

The application of TOC to Distribution is known by the name of Reposition, it is a system for scheduling and control of the distribution system. 
The goal of a distribution system is to assure sells with the minimum amount of stocks in the system. The limitation is the investment in stocks.

The application of TOC to distribution is based on the reposition of used material in each point of distribution/sell from the previous distribution point. Each distribution/sell point must keep a dimensioned stock in function of the predictable consumption along the supply time from the previous distribution point [36]. Buffers management is adapted for stock control in the different distribution/sell points.

The difference in the application of TOC to Distribution is based on the containment strategy "upstream" of the materials demanded in various distribution/sell points against the "push" strategy to protect each consumption point with its own stocks in function of the local predictions, each TOC stock protects every consumption point "Downstream" in function of the global previsions, that use to be more reliable than local ones.

Inventories must not be kept as near as they can to the market. They must be located in function of their impact on the system on its global. Change from "push" to "pull" [38].

\section{TOC Applied to Production: DBR}

Manufacturers have historically tried to balance capacity through a sequence of processes in a try to level capacity with market demand [44]. TOC instead of this, tries to balance the product flow through the system. When the flow is balanced, capacities are not. This is the reason why instead of balancing capacities it must be balanced the flow of product through the system. To change from a CONWIP system to a CONLOAD system.

TOC solution begins from the premise that different resources have different capacities [1].

TOC states that some variability cannot be eliminated and the process cannot be totally balanced, especially in JOB-SHOP environments [45].

Appears DBR as a solution to the application of TOC to production. The problem is to supply an excellent accomplishment of delivery term as the same time as inventories are minimized.

\subsection{TOC Control Measures in DBR}

Two kinds of measures are proposed:

- $\quad$ From a financial point of view (management) [46]:

o Net benefit.

○ Profitability (ROI).

○ Liquidity.

- $\quad$ From an operative point of view (exploitation) [1]

o Net income.

o Inventory.

o Operation expenses. 
The relationship between Management measures and the 2 main exploitation measures is:

$$
\begin{aligned}
B N & =T-O E \\
R O I & =(T-O E) / I
\end{aligned}
$$

There are other secondary measures like the throughoutput-dollar-day that is a measure of delivery terms accomplishment and inventory-dollar-day that measures the excess of inventory.

\section{Conclusions}

One of the main benefits of introducing TOC uses to be the generation of clear and realistic productivity indicators, related with the goal of the company.

Many companies present great hidden production capacity, caused by the waste of their bottle necks that, in a majority of cases without investments and through the implantation of TOC can flourish.

Theory of constraints is a coherent and logical frame for complex process Management knowing that is not possible to eliminate all variability.

The difference between DBR and other planning and production control techniques is the concentration of planning and control in a very few points.

While JIT can be similar to a CONWIP system, TOC would be similar to a CONLOAD system. This is a new concept.

At last we should say that some problems are usually found when introducing TOC into production and not to the rest of the company, because generally production is able to improve its own processes to the point that the limitation jumps into the market.

\section{References}

1. Noreen, E., Smith, D., Mackey, J.T.: La teoría de las limitaciones y sus consecuencias para la contabilidad de gestión. Ediciones Díaz de Santos S.A. Año de la traducción (1997)

2. Aggarwal, S.C.: MRP, JIT, OPT, FMS? Harvard Business Review 63(5), 8-16 (1985)

3. Johnson, A.: MRP? MRP II? OPT? CIM? FMS? JIT? Is any system letter-perfect? Management Review 75(9), 22-27 (1986)

4. Koziol, D.S.: How the constraint theory improved a job-shop operation. Management Accounting 69(11), 44-49 (1988)

5. Tseng, M.F., Wuz, H.H.: The study of an Easy-to-Use DBR and BM system. International Journal of Production Research 44(8), 1449-1478 (2006)

6. Ramsay, M.L., Brown, S., Tabibzadeh, K.: Push, pull and squeeze shop floor control with computer simulation. Industrial Engineering 22(2), 39-45 (1990)

7. Fogarty, D.W., Blackstone, J.H., Hoffman, T.R.: Production and Inventory Management. South-Western Publishing Co., Cincinnati (1991)

8. Cook, D.P.: A simulation comparison of traditional, JIT, and TOC manufacturing systems in a flow shop with bottlenecks. Production and Inventory Management Journal 35(1), 73-78 (1994) 
9. Duclos, K., Spencer, M.S.: The impact of a constraint buffer in a flow shop. International Journal of Production Economics 42(2), 175-185 (1995)

10. Holt, J.R.: Candid Comparison of Operational Management Approaches, pp. 1-11. Washington State University, Vancouver (1999)

11. Mabin, V., Balderstone, S.: The World of the Theory of Constraints: A review of the International Literature. Saint Lucie Press (November 1999)

12. AGII, 1998: Asociación Goldratt Institute Ibérica, La Meta: Cómo ponerla en práctica. Apuntes de un seminario, Valencia, 19 de Mayo de (1998)

13. AGII, 1998b: Asociación Goldratt Institute Ibérica, Producción: Cómo mejorar con TOC. Apuntes de un seminario, Valencia 26 y 27 de Noviembre de (1998)

14. Watson, J.K., Balcktone, J.H., Gardiner, S.C.: University of New Orleans, College of Business Administration, United Stated, The evolution of a management philosophy: The theory of constraints. Journal of Operations Management 25, 387-402 (2007), http: / / www. sciencedirect. com (Disponible 12 de junio de 2006)

15. Jacobs, R.F.: The OPT Scheduling System: A Review of a Production Scheduling System. Production and Inventory Management 24(4), 47 (1983)

16. Lambrecht, M.R., Segaert, A.: Buffer stock allocation in serial and assembly type of production lines. International Journal of Operations and Production Management 10(2), 47 61 (1990)

17. Raban, S., Nagel, R.N.: Constraint-based control of flexible flow lines. International Journal of Production Research 29(10), 1941-1951 (1991)

18. Goldratt, E.: Cadena Crítica (critical chain): Una novela empresarial sobre la gestión de proyectos, Ed. Díaz de Santos, Madrid (2001)

19. Leach, L.P.: Critical chain Project Management improves Project performance. Project Management Journal 30(2), 39 (1999)

20. Umble, M., Umble, E.: Manage your projects for success: an application of the theory of constraints. Production and Inventory Management Journal 41(2), 27 (2000)

21. Steyn, H.: An investigation into the fundamentals of critical chain project scheduling. International Journal of Project Management 19(6), 363 (2001)

22. Cohen, I., Mandelbaum, A., Shutb, A.: Multi-project scheduling and control: a processbased comparative study of the critical chain methodology and some alternatives. Project Management Journal 35(2), 39-50 (2004)

23. Leach, L.P.: Lean Project Management. In: Eight Principles for Success: Combining Critical Chain Project Management and Lean Tools to Accelerate Project Results Advanced Projects Inc., Boise, ID. Also available as e-book (2005)

24. Woeppel, M.J.: Projects in Less Time: A Synopsis of Critical Chain, Pinnacle Strategies, Plano, TX (2006)

25. Gardiner, S.C.: Measures of product attractiveness and the theory of constraints. International Journal of Retail and Distribution Management 21(7), 37-40 (1993)

26. Goldratt, E.: No es cuestión de suerte (It's not luck) Ed. Díaz de Santos, Madrid (1995)

27. Rahman, S.: The theory of constraints thinking process approach to developing strategies in supply chains. International Journal of Physical Distribution and Logistics Management 32(10), 809 (2002)

28. Watson, K.J., Polito, T.: Comparison of DRP and TOC financial performance within a multi-product, multi-echelon physical distribution environment. International Journal of Production Research 41(4), 84-93, 741-765 (2003)

29. Simatupang, T.M., Wright, A.C., Sridharan, R.: Applying the theory of Constraints to supply chain collaboration. Supply Chain Management: An International Journal 9(1), 57-70 (2004) 
30. Schragenheim, E., Ronen, B.: B. Buffer Management: a diagnostic tool for production control. Production and Inventory Management Journal 32(2), 74-79 (1991)

31. Atwater, J.B., Chakraravorty, S.S.: Using the theory of constraints to guide the implementation of quality improvement projects in manufacturing operations. International Journal of Production Research 33(6), 1737-1761 (1995)

32. Gattiker, T.F., Boyd, L.H.: A cause-and-effect approach to analyzing continuous improvement at an electronics manufacturing facility. Production and Inventory Management Journal 40(2), 26-31 (1999)

33. Monzó, J.: (2007), http: / / jmonzo . net/blogeps / eps 1 .pdf (consultado Octubre de 2.009)

34. Debernardo, H.: Boletín sobre la Teoría de las Restricciones, http: / / www. cimatic.com.ar (Noviembre de 2000)

35. Dogget, M.: A statistical comparison of three root curse analysis Tools. Journal of Industrial Technology 20(2), 2-9 (2004)

36. AGII, 1999: Asociación Goldratt Institute Ibérica, Información General (Noviembre de 1999)

37. Rizzo, T.: The Theory of Constraints, http: / / www.rogo.com/cac/rizzo11.html (Año 1997)

38. AGII, 1999b: Asociación Goldratt Institute Ibérica, Cuaderno del Asistente del Programa Satélite de Eli Goldratt (1999b)

39. Mabin, V.J., Davies, J., Kim, S.M.: Applying the TOC thinking process in supply chain management to achieve a strategic level win-win solution. Paper Presented at 4th ANZAN Operations Management Symposium, Wellington, June 6-7, pp. 2601-2613 (2006)

40. Servera, P., Quetglas, P., Horrach, M.: Vols Nous, una experiencia de TOC en el cambio estratégico de una pequeña empresa. Artículos accesibles solo para asociados, http: / / www.goldratt.es (Año 1999)

41. Woehr, W.A., Legart, D.: Unblock the Power of Your Sales Force! Delta T-Selling. Neuer Wissenschaftlicher Verlag, Vienna (2002)

42. Roff-Mars, J.: Reengineering the Sales Process. Ballistix Pty Ltd., Brisbane (2005)

43. Briceño, J.A., Montilla, A.A.: Dimensionamiento Efectivo de los amortiguadores. In: Ponencia en el 3er Congreso Iberoamericano de Gerencia de Proyecto Cadena Crítica. Caracas (Año 2000)

44. Chase, R.B., Aquilano, N.J., Jacobs, F.R.: Administración de Producción y Operaciones. In: Manufactura y Servicios, $8^{\text {a }}$ Edición. Editorial: Mc.Graw-Hill (Año 2000)

45. Cespón, R., Ibarra, S., Marrero, F.: La selección del sistema de gestión de la producción en empresas manufactureras. In: Ponencias del IX Congreso de Ingeniería de Organización, Gijón (Septiembre 2005)

46. Goldratt, E.: El Síndrome del pajar (Haystack syndrome), Ed. Díaz de Santos, Madrid (1994) 